\title{
New Ideas of Ideological and Political Course for College Students
}

\author{
Zhang Yanhui \\ Baicheng Normal University, Baicheng 137000, China \\ email: huizipin@126.com
}

\begin{abstract}
Keywords: contemporary college students; colleges and universities; ideological and political course; new teaching ideas
\end{abstract}

\begin{abstract}
With the development of the times, people's self-cultivation constantly improve, the social demand for education is also getting higher and higher. Higher education is one of the ways to improve their self-cultivation and the knowledge level of contemporary college students. They have sharp thinking and strong desire for knowledge, which poses new challenges for teachers."The ideological and political course is the compulsory basic course of the university. Therefore, in the teaching process, how to seek new teaching ideas according to the characteristics of contemporary college students is a question worth exploring.
\end{abstract}

\section{Introduction}

With the rapid development of information technology, put forward higher request to the people's level of knowledge, people's self-cultivation and cultural level is also rising. More and more people began to pay attention to the problem of children's education, especially higher education. The ideological and political education is one of the important content of university education. Therefore, in the context of the new media. According to the actual situation, take effective strategies of Ideological and political work of college students is a topic worthy of discussion.

\section{To Change the Teaching Way}

The teaching mode refers to the use of teaching aids or flexible methods of classroom teaching, and achieve the desired purpose. Teaching is the classroom teaching, but also a necessary condition for classroom teaching. And the use of teaching methods to choose whether appropriate, directly related to the success of a lesson and teaching. According to the specific the situation of teaching contents and students, choosing proper and effective teaching methods, is an important guarantee for a good class[1].

Take the Student as the Main Body, and Give full Play to the Initiative of Students. The students are learning the subject. The students' interest in the ideological and political education is low, if the teacher just only care about the teaching content of the echo what the books say, complete or not, students don't love. Especially for college students, mainly rely on conscious learning. If you are still using the traditional teaching methods, to sleep in the classroom, see more and more mobile phone such as the number of students attending the meeting seriously. Therefore, to have entered the adult college students in Ideological and political course, on some teaching content, can adopt the way of autonomous learning, let the students through the existing knowledge, access to information on the Internet, complete class exchanges, or on behalf of the students to find a few different knowledge points to speak in class, can also be the grouping debate contest and other interesting ways[2]. In this way, can arouse the enthusiasm of students, but also improve the effect of classroom teaching.

The Use of Modern Teaching Means, Increase Classroom Density, Enrich the Teaching Content. With the development of social economy, the progress of science and technology, information technology has been widely used in all walks of life. In politics teaching, teachers can use multimedia teaching course-ware, through the form, the teaching contents through pictures, text and other dynamic way, show on the big screen. The key part of the content or knowledge available different colors, or increase the distinction, which not only highlights the focus of teaching, and the 
teaching content was completed in a relaxed atmosphere, to stimulate the students' interest in Ideological and political course[3].

In addition, you can put some courses and related background information, celebrity stories, related knowledge points through the multimedia show. This is only the traditional teaching method in a blackboard, a piece of chalk pattern in time and content, by far can not be compared. High performance multimedia fast, large amount of information, not only increase the density of the classroom, enrich the teaching contents, the more important is some teaching content through multimedia used in color, movement, voice interaction, give students immersive feel, increase the sense of reality, improve teaching charm.

\section{To Improve the Teachers' own Charm}

Whether the students love a teacher, he to directly affect the course of interest. That is to say teachers' charm is one of the essential factors of teaching. Teachers' Charm is mainly reflected in the teacher's language, knowledge level, occupation accomplishment and affinity and other aspects.

The Affinity and Humanistic Care. The relationship between teachers and students is harmonious is the basis of teachers' charm. College students are active thinking, as teachers should understand their psychological characteristics, and they talk about their love topic. Such as the boys love the game, all kinds of news related to the situation at home and abroad, girls love drama, performing arts sector dynamics. To reduce the psychological distance and students, but do not let the students feel a gap with you. Now the majority of children at home are all spoiled, personality, conflict between students is inevitable thing[4]. As a teacher, especially the ideological and political teachers should promptly seize the opportunity to give students patiently the ideological work, help them to open up, to ease the contradiction, handle the relationship between the students. Because the source of students, family background, family background, character of the different character and forms are also different. For some because of family financial difficulties, inferiority complex, introverted students, should be more concerned about them, understand their specific circumstances and practical difficulties, enlighten them, help them relieve psychological pressure, let they feel like everyone else, everyone is equal, enjoy the same college life the good of all, in the classroom teaching, we should pay more attention to each student, make each student have to participate in the study, self performance, highlighting their talent, let the students feel that the teacher is not so serious, courteous and accessible. Teachers, affinity and humanistic care is a necessary condition for teachers' charm.

Knowledge Level. Familiar words "give students a glass of water, the teacher should have a bucket of water", that is their level of knowledge. Teachers should have a good lesson, must be prepared and know many times more knowledge than this lesson, so that we can do in the classroom with ease, mastery. Therefore, teachers the knowledge level is an important symbol of a teacher's basic quality, but also the teachers form itself reflects the charm. As the ideological and political lesson to teach the teachers not only need to have rich professional knowledge, ideas and research results about the more domestic and foreign literature in this area. At the same time, but also with literature, art, history, economy, etc[5]. Many aspects of the relevant knowledge, a knowledgeable teacher will be popular with students and love.

The Charm of the Language. Language is an art. The language of teachers is the key to classroom teaching. The crisp tender or rich voice, humorous language will give students an aesthetic pleasure. The ideological and political course is a strong theoretical course. This requires that teachers should not only language concise, focused, avoid producing mental tired, more teachers need to use language to abstract art theory into a simple, specific, vivid image of the language, transfer to the students. Therefore, teachers' language must accord with the age characteristics of college students, and to impart knowledge, let students accept and master knowledge.

Professional Ethics. Teachers' occupation accomplishment is an important symbol of teachers' charm. "The teacher is the engineer of the human soul", "the teacher is the most glorious sun occupation" and many good words are described and the praise of teachers. Teacher occupation is a 
teacher, teacher's words and deeds are exemplary students. Therefore, teachers should time occupation moral standards to strict demands on themselves, so they can't be the same outside and inside[6]. Speak to the students moral cultivation, moral standards while doing things themselves. Teachers should have a selfless love, dedication, devotion, set an example, require students to do their own to do first. In the classroom, do not with the classroom teaching things, such as phone calls, and independent students to talk about things. And the content of individual teachers in the classroom, and some students say and teaching content irrelevant words, saying "Gossip", in order to narrow and student age and psychological distance, to close the relationship between teachers and students, a serious violation of the teacher occupation morality. Teachers should well groomed, well-dressed, liberal and dignified, refined and cultured, prepared for each class. In the process of classroom teaching, teachers should always be full of love, enthusiasm and passion. They have done their best, earnest good each lesson, let students learn, harvest a lot. To be broad-minded toward others with the occupation, accomplishment and personality charm of their own to infection and lead the students.

\section{To Establish the Ideological and Political Education Network Platform}

Teachers can use the Internet, the establishment of Ideological and political education network platform, the effective use of new media, promote positive energy, the use of public number, and students communicate WeChat group love students, understand their ideological trends and practical difficulties, to help them solve problems, from reduced and their psychological distance. Some of the points of knowledge and the discussion to the WeChat group or the public number, which is convenient and fast, and can make it easier for students to accept, is the extension of classroom teaching is very good. And they often chat, grasp the students' thoughts, to give the necessary guidance and help them establish a correct outlook on life, the ideological and political work into in the daily life of the students[7].

\section{To Carry out Ideological and Political Education through the Rich and Colorful Activities}

To Carry out Rich and Colorful Activities, Promote Ideological and Political Education. The university is different from the ordinary primary and secondary schools, requires students to learn basic knowledge, we should pay more attention to the students' various abilities, and rich and colorful activities is an effective means of Ideological and political education. Through a variety of activities, and constantly improve the ideological and political education. For example, can hold a "welcome 7-1, sing praise of the motherland party "as the theme of the speech contest, the glorious history of the heroic deeds of the martyrs and the party, the patriotic education to students are good, strengthens the national pride through calligraphy competition, understand the traditional culture of the Chinese nation, the use of new media, through the online test, humanistic knowledge contest, in" the campus art festival "in the activity, the students through the various performances, such as playing Guzheng, folk dance, not only enable students to understand the Guzheng beautiful melody, dance charm, and display in the students' talent In the process, virtually penetration of humanistic education.

The Ideological and Political Education and Practice. The ideological and political education is not only the theory, it can come out from the little things in life. The ideological and political education and practice. For example, in the number of students there is a high consumption phenomenon, they know the hardships of parents and is not easy to understand, the heart should be more for the parents can take some of the pressure solution difficult. Parents, cherish the hard-earned every penny, but in fact not only through the work study program to help my parents to ease the economic pressure on families, rather than eating than wearing, hedonistic vanity. Based on this, the ideological and political education more from the reality, combined with the specific circumstances of the students, and often carry out some related ideological and political education the activities such as "I have important things parents do the theme of the mission will be" I love the national hero "in the speech contest. Organization members and the majority of young people 
through the Internet to watch inspirational speeches and really The real story, using the computer to write about it and experience, and then sent to the specified mailbox by e-mail. The ideological and political teaching into practice, increase the experience of educating students, so as to continuously improve the effectiveness of Ideological and political education.

Participate in Various Charity Activities, Strengthen the Sense of Social Responsibility. Nowadays college students generally rely on strong sense of self-care ability is poor, lack of emotion. In view of this phenomenon, the use of spare time, often organized members and young students to participate in various social activities, enhance the sense of social responsibility. They can go to the orphanage or retirement home, experience the warmth of affection. The welfare of children are orphans or disabled, welfare is their home. The school can give children love to carry out activities, send them a small gift, a book, a little food, or give them a story and play games with them, they will let the children happy. You can also go to tread on air support for the elderly to do something, to help them wash their clothes, their haircut, and even chat with them, they will appreciate and moved, see this, will give youth, light of heart from care the students bring a spiritual shock, so that they have a cognizance of the self value sense, see the meaning of their own existence, cherish today's happy life, cherish their own family. They can go to the train station or the traffic hub volunteer. The rapid development of information technology, the Internet is widely used in all walks of life, the use of automatic ticket machines, ticket vending machines, has brought great convenience to us, but there are still a few people will not understand, learn and can organize students to volunteer to go to the train station help some people, tickets, tickets, teach them how to correctly use the ticket machine, maintaining the order, can also go to the traffic hub, crowded places to maintain traffic order, guide foreign personnel across the road right, as the route and direction of travel. Although they that are trivial, but the students can also exercise and the inspiration from it, it can experience the importance and significance of social responsibility.

\section{Summary}

The ideological and political course is a compulsory course for college students, the theory is strong, but not too love. How to do well the ideological and political course is a severe test of the teachers, but also a challenge of teaching ability. According to the specific circumstances of the students to analyze the problems and methods to improve the teaching effect, to take reasonable and effective measures to stimulate students' interest in learning, improve the ideological and political teaching, strengthen students' moral and ideological consciousness, to cultivate them into the era of qualified college students and make unremitting efforts.

\section{Reference}

[1] Bai Chuan, Liu Guojiang. Ideological and political theory course of confusion and beyond [J]. Journal of Puyang Vocational and Technical College, 2015,06:137-139.

[2] Liu Xueqing. Political theory study of [J]. teaching reform of the course of ideological characteristics and the wisdom of the contemporary college students, 2016,02:106.

[3] Luo Wenfang, Zhang Desheng, Peng Xianbing. With the help of professional practice thinking platform for ideological and political course practice teaching mode [J]. Journal of Jiangxi Jouth Vocational College, 2016,02:64-66.

[4] Jiang Hong. Analysis of the contemporary college students in Ideological and political teaching of new ideas [J]. South China Journal, 2016,04:102-104.

[5] Li tan. The ideological and political education in the humanities research [D]. Hebei Normal University, 2016.

[6] Wang Fengcheng. Cultivation of students' scientific literacy based on the theory of STS [D]. Yanshan University.2014. 
[7] Fu Changzhao. Research on [J]. education innovation of College Ideological and political education and occupation of classroom teaching mode, 2015,30:41-43. 